\title{
Chromosomal Evolution in Some Iranian Artemisia L. using Numerical Analysis of Karyotypes
}

\author{
Hamid Reza Naseri ${ }^{1, *}$, Hossein Azarnivand ${ }^{1}$ and Mohammad Jafari ${ }^{1}$ \\ ${ }^{1}$ Department of Arid and Mountainous Rangelands Reclamation, Faculty of Natural \\ Resources, University of Tehran, P.O. Box 315854314 Karaj, Iran
}

Received February 4, 2009; accepted March 9, 2009

\begin{abstract}
Summary A karyological study of seven taxa (four sections) of genus Artemisia L. from Azerbaijan region (Iran) is presented. We found the two usual basic numbers in the genus $x=9$, the most common one (in three diploid and two tetraploid populations) and $x=8$ (in two diploid populations).The intra- $(A 1)$ and interchromosomal ( $A 2)$ asymmetry index, which does not depend on chromosome number or chromosome size showed asymmetry index based on $A 1$ value has indicated that the chromosomes in some Iranian Artemisia evolved in order of section Absinthium and Artemisia meanwhile section Seriphidium and Dracunculus are close to each other but they can separate from Section Absinthium and Artemisia.
\end{abstract}

Key words Artemisia, Asteraceae, Chromosome, Karyotype.

The Anthemideae is an important tribe Asteraceae that is contains about $8 \%$ of total genera and $13 \%$ of the species of the Astraceae (Heywood et al. 1977). The genus Artemisia one of the largest and most widely distributed of the nearly 100 genera in the tribe Anthemideae. This genus contains a great number (more than 200 to more than 500, depending on the authors; (Ling 1991a, b, Bremer and Humphries 1993, Mabberley 1997, Vallès and Siljak-Yakovlev 1997, Torrell et al. 1999, Torrell and Vallès 2001) of species.

The 400 and more known species of Artemisia are mainly found in Asia, Europe and North America, but a few species occurs in most temperate countries. Asia seems to show the greatest concentration of species with 150 accessions for china (Hu 1965), 174 in the ex U.S.S.R (Poljakov 1961), 50 in Japan (Kitumara 1939, 1940) and about 37 reported to occur in Iran (Mozafarian 1998). These species of the genus in Iran are found from seacoast of Caspian Sea to high mountains, and most of them can be found in vast steppes of Iran.

According to Naseri et al. (2006), they include some introduced species, which have been cultivated for food use in Iran. Artemisia genus have a high economic value in several fields: food (absinth, A. absinthium L. and other taxa, such as A. genipi, used to make liquors; spices such as tarragon or estragon, A. dracunculus L.), medicine (many antihelminthic species such as $A$. santonicum L. and related taxa, antimalarian such as $A$. annua L.), forage ( $A$. herba-alba Asso and related species in African and Asian steppes and semi deserts and A. tridentata Nutt. and related species in North American shrub lands), ornamentals (A. absinthium among many others). Some taxa, such as $A$. verlotiorum Lamotte, are invasive weeds which can adversely affect harvests.

Artemisia has been divided classically into four groups treated as sections or subgenera (Artemisia, Absinthium, Dracunculus and Seriphidium), but this number has increased with the proposal of the Tridentatae, which is endemic to North America (McArthur et al. 1981). Ling (1982, 1991a, b, 1995a, b) proposed the separation of one of the sections as an independent genus, Seriphidium (Besser ex Hook.) Fourr., which was accepted by Bremer and Humphries (1993) and Bremer (1994) in their respective cladistic revisions of the tribe Anthemideae and the family Asteraceae.

*Corresponding author, e-mail: hrnaseri@ut.ac.ir 
Artemisia has two basic chromosome numbers, with ploidy levels ranging from diploid to dodecaploid for $x=9$ and from diploid to hexaploid for $x=8$ (Vallès and Siljak-Yakovlev 1997, McArthur and Sanderson 1999, Vallès and McArthur 2001). Palaeotological data suggest that the mountain region of Artemisia was most probably in the mountain regions of north-western Asia in mid-Cenozoic (Ling 1982). The most important center of diversity is temperate Asia, although there are dispersed foci of section in temperate and cold region of Erusia and North America (Ling, 1982). The finding of different poloidy levels in these and other Artemisiinae species in Asia also supports the hypothesis of this origin of speciation.

Many species of Artemisia are not always well known and a world revision of the genus, from a systematic point of view is needed (Oliva and Vallès 1994). Karyological data may be very helpful in establishing systematic and evolutionary ship within the genus. In spite of the very large number of counts in the tribe, chromosomal data on Iranian populations are scarce.

In this study we provide karyomorphological data with somatic chromosome numbers 7 populations belonging to the 7 taxa, Artemisia fragrans Willd, A. spicigera Willd, A. vulgaris Rat, A. campestris L., A. scoparia Waldst. and Kit, A. absinthium L. and A. chamaemelifolia Vill. in Iran.

\section{Materials and methods}

Plants and ripe achenes were collected from natural population in different ecological regions of Eastern Azerbaijan province (Iran). Herbarium vouchers of the populations studied are deposited in the Herbarium of RIFR (Research Institute of Forests and Rangelands, Tehran). The species studied are listed in Table 1.

For the study we used root tip meristems from seedlings obtained from the germination of achenes on wet filter paper in Petri dishes or from plants cultivated in pots. Ripe achenes were placed on wet filter in Petri dishes and left in the dark at germinator temperature $\left(20^{\circ}-22^{\circ} \mathrm{C}\right)$. Adults' plants also collected and were grown in pots in greenhouse conditions. Root tip meristems were obtained from the seedling or from the plants living in pots. They were pretreated with saturated solution of $\alpha$-bromonaphthalene at room temperature for $4 \mathrm{~h}$ at $15^{\circ} \mathrm{C}$. These speciments fixed in absolute ethanol and glacial acetic acid $(3: 1)$ for at least $12 \mathrm{~h}$ at $4^{\circ} \mathrm{C}$. Root tips were hydrolysed in $1 \mathrm{M} \mathrm{HCL}$ for $5 \mathrm{~min}$ at $60^{\circ} \mathrm{C}$, squashed in a droplet of $45 \%$ acetic acid, dyed by Aceto- Iron-Hematoxylin. The preparation was observed with an optical microscope at magnification of $1000 \mathrm{X}$. The best metaphasical plates were drawn with a camera and photographed. The counts were carried out bearing in mind the comments of Favarger (1978) to avoid mistakes in chromosome counting (basically the following: not being influenced by previous reports; obtaining good metaphases, especially in polyploid taxa; having the slides examined by different experienced people in case of doubt; and making a correct plant material determination). At least ten metaphases were examined per population, with the five best selected for making idiograms.

The following parameters were estimated in each metaphase plate to characterize the karyotypes numerically; (1) total karyotype length (TKL); (2) mean chromosome length (MCL); (3) chromosome length range (CLR); (4) lengths ratio of long and short arms of chromosome according to Levan et al. (1964) (L/S); (5) intrachromosomal asymmetry index $(A 1)=1-[\Sigma(b / B) / n]$; and (5) interchromosomal asymmetry index $(A 2)=s / x$, where $b$ and $B$ are the mean length of short and long arms in every homologous chromosome groups, respectively, $n$ is the number of homologues, $s$ is the standard deviation, and $x$ the mean chromosome length. Karyotype asymmetry was estimated using the mean centromeric index, the ratio of the shortest/longest pair and according to the $A 1$ and $A 2$ indices (Romero 1986). Symmetry classes (SC) according to Stebbins (1971) of the populations studied were done and Chromosomal formula according to Levan et al. (1964) obtained for all species studied. 


\section{Results}

Our Results showed five population belong to taxa with basic number $x=9$, the most common one in the genus. Among this population we find three diploid and two tetraploid mean while two diploid population belong to taxa basic number $x=8$. Chromosome number in seven Iranian Artemisia species counted were listed follows; $2 n=36$ for A. spicigera, A. campsteris and $2 n=18$ for A. fragrans, A. absinthium, A. chamaemelifolia and finally $2 n=16$ for A. vulgaris and $A$. scoparia. Table 2 presented the data on poloidy level, chromosome formula, TKL, MCL, CLR L/S, interachromosomal asymmetry index $(A 2)$, interchromosomal asymmetry index $(A 2)$ and SC.

Their mitotic metaphase chromosomes were shown in Fig. 1 and Haploid ideograms of seven Iranian Artemisia species were indicated in Fig. 2.

Artemisia scoparia showed the shortest $(48.56 \mu \mathrm{m})$ and $A$. spicigera the longest $(122.99 \mu \mathrm{m})$ TKL of all species. A. scoparia and A. fragrans had smallest MCL $(3.04 \mu \mathrm{m})$ mean while the largest MCL belonged to $A$. absinthium $(3.85 \mu \mathrm{m})$. Other species were significantly different from each other (3.09-3.67 $\mu \mathrm{m})$. A. scoparia, A. campestris, A. chamaemelifolia and A. fragrans, had lowest L/S that weren't significantly different (1.47-1.65). A. vulgaris and Artemisia absinthium showed highest L/S (2.88-3.14) meanwhile $A$. spicigera had medium L/S (2.20).

Artemisia fragrans had the lowest intrachromosomal asymmetry index $A 1(0.17)$, and $A$. campestris, A. spicigera, A. vulgaris, A. scoparia, and A. chamaemelifolia, showed relatively small $A 1$ (0.18-0.34). The largest $A 1$ belonged to A. absinthium (0.60). A. scoparia showed the lowest (0.04) and $A$. absinthium the highest (0.26) $A 2$ values of all species. None of other species were significantly different from each other (0.07-0.13). These results of $A 1$ and $A 2$ were shown graphically in Fig. 3 and Fig. 4 for both species and sections. Symmetry types of Stebbins in these seven Artemisia species showed all species were located in same class (1A).

\section{Discussions}

The results obtained confirm the existence of two basic chromosome numbers in the genus. Five of the studied taxa have $x=9$, the most common basic number in the genus Artemisia, the tribe Anthemideae and the family Asteraceae as well (Solbrig 1977, Schweizer and Ehrendorfer 1983, Oliva and Valle's 1994, Valle's and Silja-Yakovlev, 1997). Among the considered taxa, Artemisia vulgaris and $A$. scoparia have the less common basic number $x=8$, this is evidence for the descending dysploidy that occurs in the genus (Vallès and Siljak-Yakovlev 1997, Torrel et al. 2001). This phenomenon is common in many genera of the family Asteraceae (Fernandez Casas and Susanna 1986, Siljak-Yakovlev 1996, Vallès et al. 2001, 2005).

In this study, we have provided additional karyomorphological parameter using intra- $(A 1)$ and interchromosomal asymmetry index $(A 2)$, which does not depend on chromosome number or chromosome size (Romero 1986). Fig. 3 indicates scatter diagram that showing the relation between intra- and interchromosomal asymmetry. The section Absinthium shows high value for (A2) 1 and it is distinguished separately meanwhile for the section Artemisia, Dracunculus and Seriphidium are difficult to distinguish in their interchromosomal asymmetry index (A2). On the other hand, the intrachromosomal asymmetry index $(A 1)$ indicates a difference between four groups of Iranian Artemisia Fig. 4. The section Dracunculus and Seriphidium show relatively smaller $A 1$ values (0.17-0.22), section Artemisia intermediate $A 1$ value (0.29-0.34) and section Absinthium higher $A 1$ value (0.60) (Table 2). Each section seems to be more affected with $A 1$ values than with $A 2$ value. Stebbins (1971) has suggested that asymmetrical karyotypes are more advanced than symmetrical ones in relation to phylogeny and evolutionary processes. Our asymmetry index based on $A 1$ value has showed that he $A 1$ parameter is useful for estimation of evolutionary relationships among some subgenera or sections of genus Artemisia. These results have been obtained by other authors (Mato- 


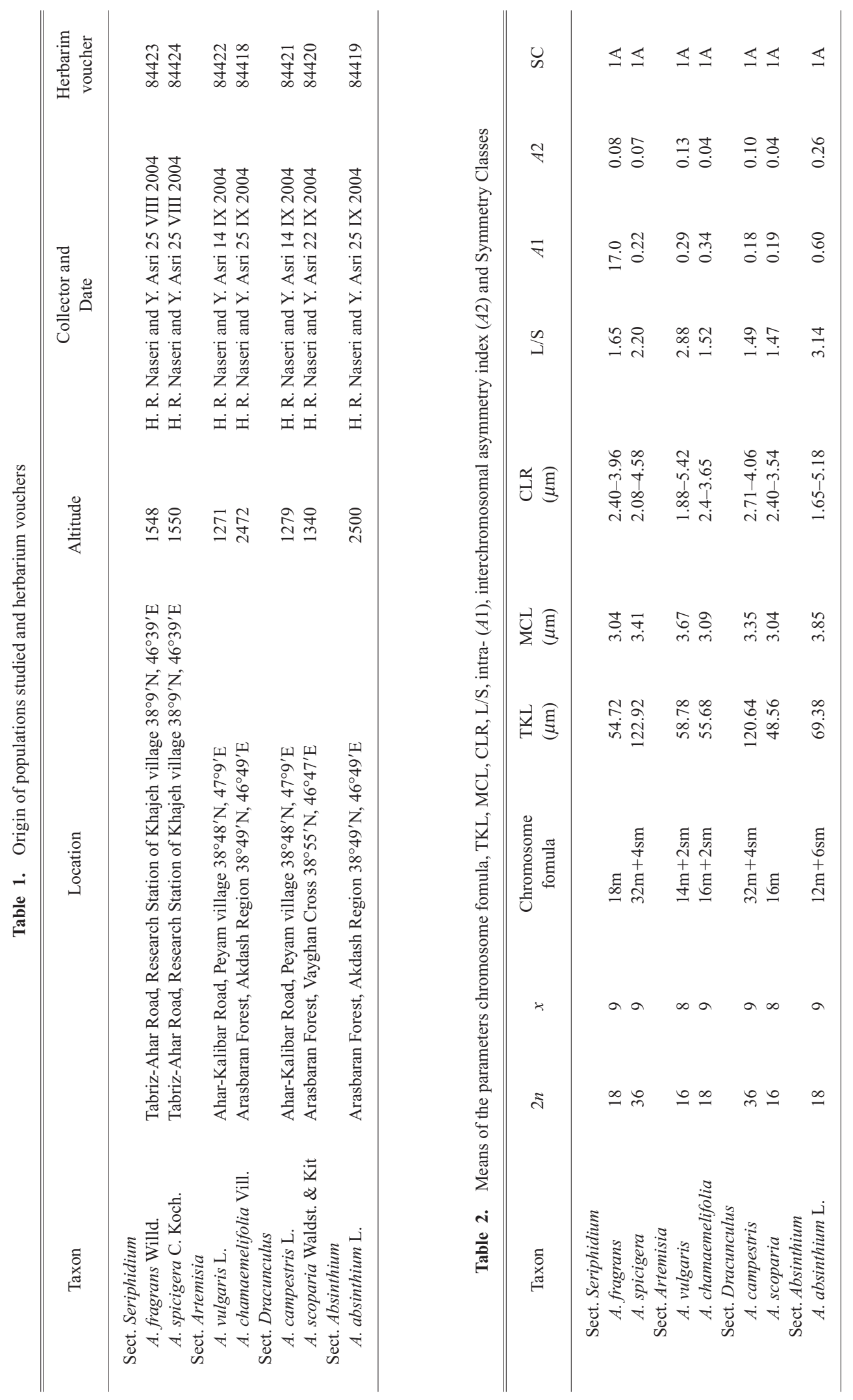




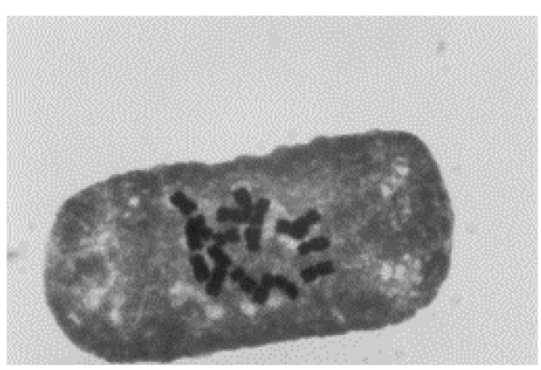

A

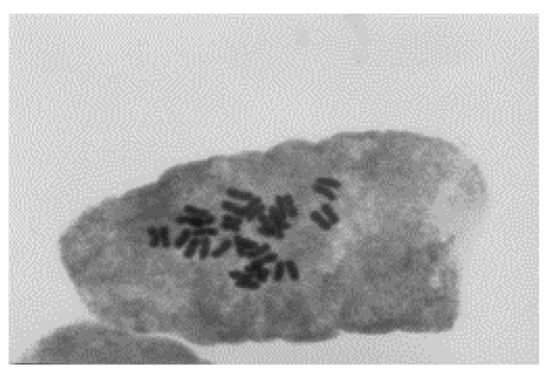

C

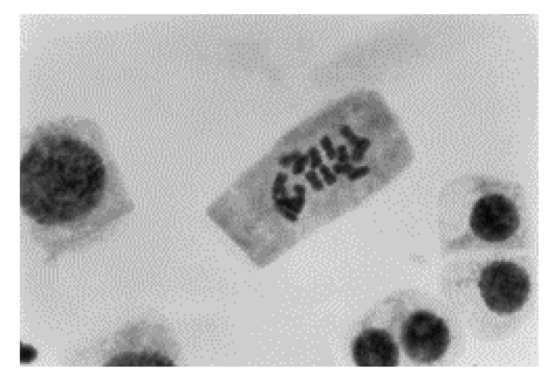

E

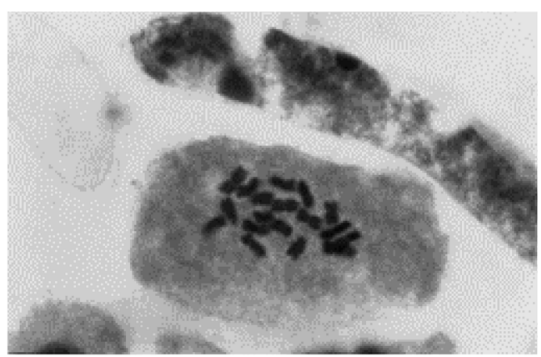

G

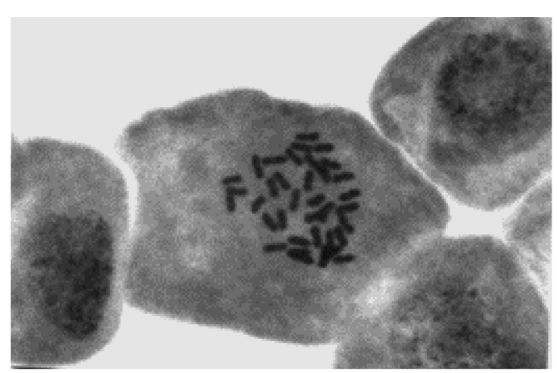

B

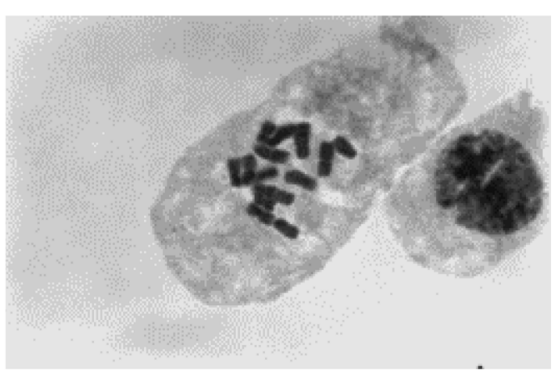

D

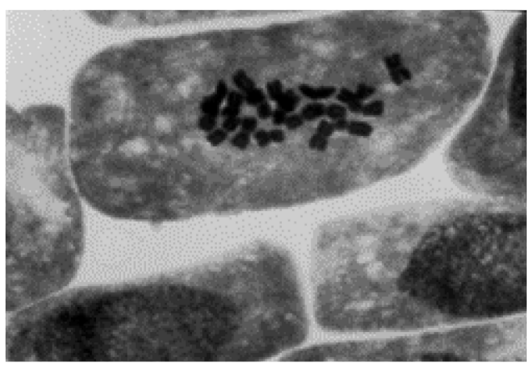

F

Fig. 1. Somatic chromosomes at metaphase of seven species of Iranian Artemisia. A: A. fragrans $(2 n=18)$. B: A. spicigera $(2 n=36)$. C: A. campestris $(2 n=36)$. D: A. Vulgaris $(2 n=16)$. E: A. scoparia $(2 n=16)$. F: A. absinthium $(2 n=18)$. G: A. chamaemelifolia $(2 n=18)$. Scale bar represents $5 \mu \mathrm{m}$ for A to $\mathrm{G}$. 

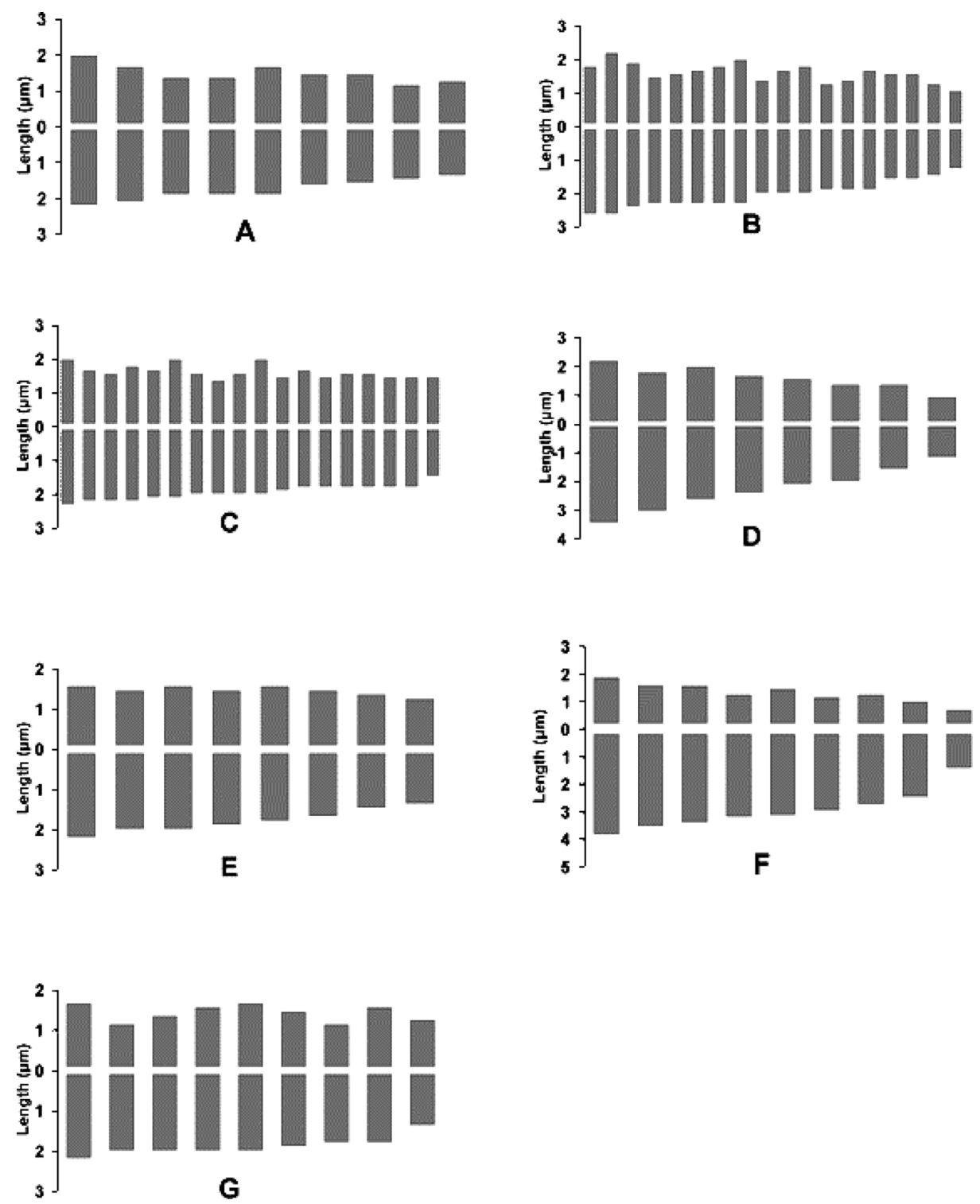

Fig. 2. Haploid ideogram of seven species of Iranian Artemisia. A: A. fragrans $(2 n=18)$. B: A. spicigera $(2 n=36)$. C: A. campestris $(2 n=36)$. D: A. Vulgaris $(2 n=16)$. E: A. scoparia $(2 n=16)$. F: A. absinthium $(2 n=18)$. G: A.chamaemelifolia $(2 n=18)$.

ba et al. 2007).

Comparing between our results and other results from different region showed in most species we can confirm other results.

Section Seriphidium: Three reports, also of $2 n=18$, have been published to evaluate for A. fragrans by Kawatani and Ohno (1964), Nazarova and Pogosian (1970) and Torrel et al. (2001). Our results now confirm this chromosome number from plants collected directly from a natural population. Result for A. spicigera is $2 n=36$ and this is the second count on this taxon in Iran. Our count agrees from the only previous report Rabiee (2001). This group being the only one in the genus (together with the North American endemic section Tridentatae, not treated here) which 


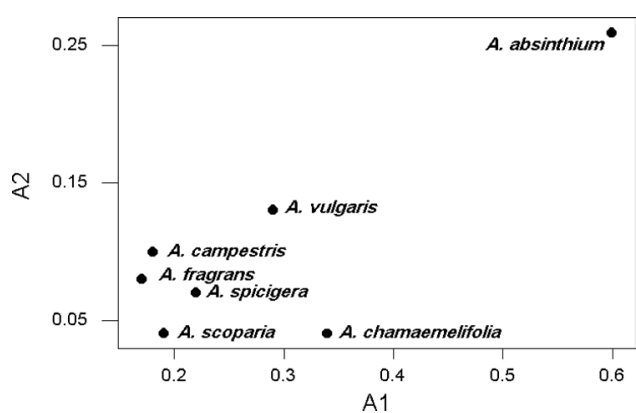

Fig. 3. Graphic representation of the asymmetry indices of Romero (1986) of the species of Artemisia studied.

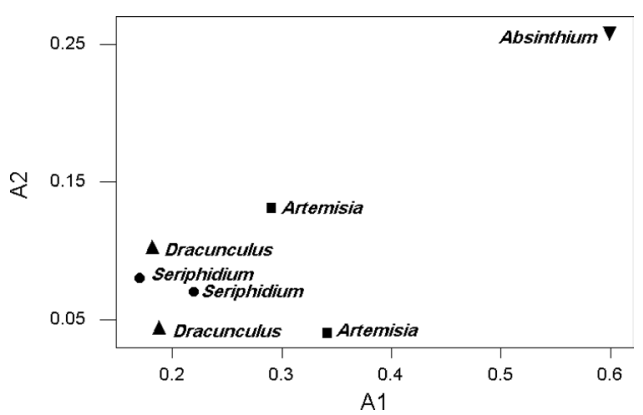

Fig. 4. Graphic representation of the asymmetry indices of Romero (1986) of the sections of Artemisia studied.

lacks dysploidy, with $x=9$ as the unique basic chromosome number.

Section Artemisia: Many counts with different results $(2 n=16,18,24,36$ and 45) have been published for very common species A. vulgaris all over the world (Fedorov 1969, Ornduff 1969, Moore 1973, Goldblatt 1981, Agapova et al. 1990), with no correlation between chromosome number and geographical distribution. Most of the counts report $2 n=16$ chromosomes, as in the present study. Our count confirms other results from Iran (Rabiee 2001, saedi 2003). A. chamaemelifolia is largely distributed in Eurasian mountains: Spanish Sierra Ne- presvada,Cantabrian chain, Pyrenees, Alps, Carpathians, Caucasus and the mountains of Iran (Peccenini 1994). previous studies dealing with the chromosome number of this taxon; from Stockholm, probably from Botanic Garden material, as the species is not wild there (Kawatani and Ohno 1964), Cantabrian chain and Pyrenees (Torrell et al. 1999), and Iran (Tavassoli and Derakhshandeh-Peikar 1993, Torrel et al. 2001). In all cases the reported chromosome number is $2 n=18$. Our results confirm pervious studies for this taxon.

Section Dracunculus: The chromosome number $2 n=36$ obtained in population of A. campestris agrees with other reports of tetraploid level for this taxon (Kawatani and Ohno 1964, Kuzmanov 1993, Oliva and Valle's 1994) for which diploid population have also been reported (Moore 1982, Stahevich and Wojats 1988, Valle's and Torrell 1995).

Many chromosome counts have been published for A. scoparia, this widespread Eurasian species, our results for this Iranian populations agree with most of them: Khoshoo and Sobti (1958), Chuksanova et al. (1968) from Russian far east, Bhat et al. (1974) and Kaul and Bakshi (1984) from Kashmir and other Himalayan regions, Podlech and Bader (1974) from Afghanistan, Maájovsky and Murín (1987) from Slovakia, Kuzmanov (1993) from Bulgaria, Volkova and Boyko (1986) from Russian far east, Krasnikov and Lomonosova (1990) from Siberia, and Tavassoli and Derakhshandeh-Peikar (1993) from Iran. At present study $2 n=16$ for $A$. scoparia is confirmed. Torrel et al. (2001) stated that a typographic mistake $(2 n=18$ is written instead of $2 n=16$ in the text, even though the karyograms contain 16 chromosomes) is reproduced by Goldblatt and Johnson (1990), who erroneously report $2 n=18$. Nevertheless, there are some other counts indicating a diploid $(2 n=18)$ or tetraploid $(2 n=36)$ level based on $x=9$ (Kawatani and Ohno 1964, Kovanda 1972, Yan et al. 1989, Qiao et al. 1990).

Section Absinthium: We found $2 n=18$ chromosomes in population of $A$. absinthium This number agrees with previous reports from Iran like Derakhshandeh-Peikar (1993), Rabiee (2001) and Saedi (2003). Our results confirmed reports from other authors(Kawatani and Ohno 1964, Vallès and Torrel 1995). Our count agrees with many others from different territories (Watanabe 2002 and references therein). This number is shown to be very stable, because it is also the same in many other reports based on plants from different regions. 
It is also being noted that Life cycle also correlates with genome size (Bennett 1995). It has been proposed that, within a genus, an increase in nuclear DNA content implies a longer cell cycle, thus annual plants usually have lower DNA amounts than perennial ones (Rees and Narayan 1981). Nagl and Ehrendorfer (1974) reported this tendency in some members of the tribe Anthemideae, including two (one annual and one perennial) Artemisia species. This is now confirmed, in this genus, by the annual species A. scoparia which shows the lowest TKL amounts of all the present populations, its TKL value is lower than that of the perennial species and TKL strongly correlated with genome size and DNA content.

Two of the seven populations are tetraploid, which occurs frequently in Artemisia and is consistent with assessments of many authors (Ehrendorfer 1980, McArthur et al. 1981, Oliva and Vallès 1994, Matoba et al. 2007) who considered polyploidy as common and one of the main evolutionary mechanisms in plants in general and in the Anthemideae and Artemisia in particular. Most of Artemisia that colonizes extreme and arid habitats is polyploids. This fact supports the hypothesis that polyploids have more tolerance of extreme environmental conditions (Otto and Whitton 2000).

The high frequency of polyploidy in plants studied here and other research leads us to consider that Artemisia is continuously developing genetic and ecological evolutionary mechanisms leading to diversification and speciation, particularly in Asia which is regarded as the main center of diversification of the genus.

\section{Acknowledgements}

We are indebted to Y. Asri, K. Saedi, J. Pour Rezaee, and Z. Mehrabanfar N. for their help in the collection of plant material and references. A. Jalili, (RIFR) is thanked for supporting us in the filed and lab work, and Mrs. Rabiee her suggestions, which improved our study.

\section{References}

Agapova, N. D., Arkharova, K. B., Vakhtina, L. I., Zemskova, E. A. and Tarvis, L. V. 1990. Chisla Khoromosom tsvetkoykh rastenii flory SSSR. Aceraceae-Menyanthaceae-Numeri chromosomatum. Nauka, Leningerad, Russia.

Bennett, M. D. and Leitch, I. J. 1995. Nuclear DNA amounts in angiosperms. Ann. Bot. (London), 76: 113-176.

Bhat, B. K., Bakshi, S. K. and Kaul, M. K. 1974. Reports. In: Löve Á, ed. IOPB chromosome number reports, XLVI. Taxon 23: 809.

Bremer, K. and Humphries, C. J. 1993. Generic monograph of the Asteraceae-Anthemideae. Bull. Br. Mus. (Nat. Hist.) Bot. 23: 71-171.

- 1994. Asteraceae. Cladistics and classification. Portland: Timber Press.

Chuksanova, N. A., Sveshnikova, L. I. and Alexandrova, T. V. 1968. Materialy k kariologii semeistva Slozhnotsvetnykh/Data on karyology of the family Compositae Giseke. Citologija 10: 198-206.

Ehrendorfer, F. 1980. Polyploidy and distribution. In Polyploidy: Biological relevance. Edited by W.H. Lewis. Plenum Press, New York. pp. 45-60.

Favarger, C. 1978. Philosophie des comptages de chro- Scimosomes. Taxon 27: 441-448.

Fedrov, A. A. (editor). 1969. Khromosomnye chisla tsvetkovykh rastenii. Chromosome numbers of flowering plant. Nauka, Leningerad, Russia.

Fernandez Casas, J. and Susanna, A. 1986. Monografia la section Chamaecyanus Willkomm del genero Centaurea L. Treballs de l'Institut Botanic de Barcelona 10: 5-174.

Goldblatt, P. 1981. Index to plant chromosome numbers 1975-1978. Monogr. Syst. Bot. Miss. Bot. Gard. 5.

— and Johnson. 1990. Index to plant chromosome numbers 1986-1987. Monographs in Systematic botany from the Missouri Botanical Garden, vol. 30. Missouri Botanical Garden, St. Louis, MO

Heywood, V. H. Harborne, J. B. and Turner, B. L. 1977. The biology and Chamistry of the Compositae, Academic Press, London, vol. 1, chapter1, pp. 852-888.

Hu, S. Y. 1965. The compositae of China I. Q.J. Taiwan Mus. 18: 1-136.

Kaul, M. K. and Bakshi, S. K. 1984. Studies on the genus Artemisia L. in north-West Himalaya with particular reference to Kashmir. Folia Geobotanica et Phytotaxonomica 19: 299-306. 
Kawatani and Ohno. 1964. Chromosome numbers in Artemisia. Bull. Natl. inst Hyg. Sci. (Tokyo) 82: 183-193. (in Japanese)

Khoshoo, T. N and Sobti, S. N. 1958. Cytology of Indian Species of Artemesia [sic]. Nature 181: 853-854.

Kitamura, S. 1939. A classification of Artemisia. Acta Phytotax. Geobot. 8: 62-66.

— 1940. Compositae Japonicae. Pars Seconda. Mem. Coll. Sci. Kyoto Univ. 25(3) art. 9: 286-446.

Kovanda, M. 1972. Somatic chromosome numbers for some Asteraceae. Rhodora 74: 102-116.

Krasnikov, A. and Lomonosova, M. 1990. Chisla khromosom predstaviteliei nekotorikh semestv sosudistykh rastenii flory Novosibirskoi oblasti, I. Chromosome numbers in representatives of some families of vascular plants in the flora of the Novosibirsk region, I. Botanicheskii Zhurnal 75: 116-11.

Kuzmanov, B. 1993. Chromosome numbers of Bulgarian angiosperms: An introduction to a chromosome atlas of the Bulgarian flora. Flora Mediterranea 3: 19-163.

Levan, A., Fredga, K. and Sandberg, A. 1964. Nomenclature for centromeric position on chromosomes. Hereditas 52: 201-220.

Ling, Y. R. 1995a. The New World Artemisia L. In: Hind DJN, Jeffrey C, Pope GV, eds. Advances in Compositae Systematics. Kew: Royal Botanic Gardens, 255-281.

- 1995b. The NewWorld Seriphidium (Besser) Fourr. In: Hind DJN, Jeffrey C, Pope GV, eds. Advances in Com-positae Systematics. Kew: Royal Botanic Gardens, 283-291.

— 1991a. The Old World Seriphidium (Compositae). Bull. Bot. Lab. N.-East. For. Inst. 11: 1-40.

- 1991b. The Old World Artemisia (Compositae). Bull. Bot. Lab. N.-East. For. Inst. 12: 1-108.

- 1982. On the system of the genus Artemisia L. and the relationship with its allies. Bulletin of the Laboratory of the North-East Forest Institute 2: 1-60.

Májovsky, J., Murín, A. eds. 1987. Karyotaxonomicky pre-hl'ad flóry Slovenska. Bratislava: Veda vydavatel'stvo Slov-enske jAkadémie Vied.

Mabberley, D. J. 1997. The plant-book. A portable dictionary of the higher plants. Cambridge University Press, Cambridge, U.K.

Matoba, H., Nagano, K. and Hoshi, Y. 2007. The Tendency of Chromosomal Evolution in Some Japanese Artemisia using Numerical analysis of Karyotypes. Cytologia 72: 181-188.

McArthur, E. D., Pope, C. L. and Freeman, D. C. 1981. Chromosomal studies of the subgenus Tridentatae of Artemisia: evidence for autopolyploidy. American Journal of Botany 68: 589-605.

— and Sanderson, S. C. 1999. Cytogeography and chromosome evolution of subgenus Tridentatae of Artemisia (Asteraceae). Am. J. Bot. 86: 1775-1754.

Moore, D. M. 1973. Index to plant chromosome numbers for 1967-1971. Regnum Veg. 90: 1-539.

- 1982. Flora Europaea. Check-list and chromosome index. Cambridge University Press, Cambridge, U.K.

Mozaffarian, V. 1998. A Dictionary of Iranian plant names, Farhang Moaser Publishing.

Nagl, W. and Ehrendorfer, F. 1974. DNA content, heterochromatin, mitotic index, and grown in perennial and annual Anthemidea (Asteraceae). Plant Syst. Evol. 123: 737-740.

Naseri, H. R., Azarnivand, H. Sefidkon, F. and Asri, Y. 2006. Essential oil composition of Aretmisia absinthium, Procciding of Information system in sustainable agriculture, agroenvironment and food technology, Volos, Greece. pp. $672-676$.

Nazarova, E. A. and Pogosian, A. I. 1970. Chisla khromosom ne-Comkotorykh kavkazskikh vidov rastenii. Biologicheskii Zhurnal Armenii 23: 96-98.

Oliva M. and Valle's J. 1994. Karyological studies in some taxa of the genus Artemisia (Asteraceae). Canadian Journal of Botany 72: 1126-1135.

Ornduff, R. 1969. Index to plant chromosome number for 1967. Regnum Veg. 59: 1-129.

Otto, S. P. and Whitton, J. 2000. Polyploid incidence and evolution. Annual Review of Genetics 34: 401-437.

Peccenini, S. 1994. Distribuzione di Artemisia chamaemelifolia Vill. sulle Alpi. Revue Valdôtaine d'Histoire Naturelle. 48 (suppl.): 421-423.

Podlech, D. and Bader, O. 1974. Chromosomenstudien an Afghanischen Pflanzen II. Mitteilungen der Botanischen Staatssammlung München 11: 457-488.

Poljakov, P. P. 1961. Systematic studies in the genus Artemisia L. Trudy Ins. Bot. Akad. Nauk. Kazakh. SSR. Alma Acta. 11: $134-177$

Qiao, Y. M., Yan, X. X. and Zhang, S. Z. 1990. A study on the chromosomes of 20 species of the genus Artemisia. Grassland China 1990: 24-31.

Rabiee, M. 2001. Botanical and ecological studies of the species of Artemisia in Gillan province, Iran, Ms.C thesis, University of Tehran.

Rees, H. and Narayan, R. K. J. 1981. Chromosomal DNA in higher plants. Philos. Trans. R. Soc. London B Biol. Sci. 292: 569-578.

Romero, Z. C. 1986. A new method for estimating karyotype asymmetry. Taxon 35: 526-530. 
Saedi, K. 2003. Botanical and ecological studies of the species of Artemisia in Azerbaijan province, Ms.C thesis, University of Tehran.

Schweizer. D. and Ehrendorfer, F. 1983. Evolution of C-band patterns in Asteraceae-Anthemideae. Biologisches Zen-tralblatt 102: 637-655.

Siljak-Yakovlev, S. 1996. La dysploidie et l'evolution du caryotype. Bocconea 5: 211-220.

Solbrig, O. T. 1977. Chromosomal cytology and evolution in the family Compositae. In: Heywood V. H., Harborne, J. B., Turner, B. L., eds. The Biology and Chemistry of the Comkotorykh positae, vol. I. London, New York, San Francisco: Academic Press, 269-281.

Stahevich, A. E. and Wojats, A. J. 1988. Choromosome numbers of some North American specis of Artemisis (Asteraceae). Can. J. Bot. 66: 672-676.

Stebbins, G. L. 1971. Chromosomal evolution in higher plants. E Arnold, London.

Tavassoli, A. and Derakhshandeh-Peikar, P. 1993. Chromosome numbers of some Artemisia L. species from Iran. Iranian Journal of Botany 6: 169-175.

Torrel, M., Vallès, J., Garcia-Jacas, N., Mozaffarian, V. and Gabrielian, E. 2001. New or rare chromosome counts in the genus Artemisia L. (Asteraceae, Anthemideae) from Armenia and Iran. Botanical Journal of the Linnean Society 135: 51-60.

—, Garcia-Jacas, N., Susanna, A. and Vallès, J. 1999. Phylogeny in Artemisia (Asteraceae, Anthemideae) inferred from nuclear ribosomal DNA (ITS) sequences. Taxon 48: 721-736.

Vallès, J. and McArthur, E. D. 2001. Artemisia systematics and phylogeny: cytogenetic and molecular insights. In Proceedings:Shrubland Ecosystem Genetics and Biodiversity, June 13-15, 2000, Provo, Utah. Proceedings RMRS-P-000. Edited by E. D. McArthur and D. J. Fairbanks. United States Department of Agriculture Forest Service, Rocky Mountain Research Station, Ogden, Utah. In press.

- Garnatje, T., Garcia, S., Sanz, M. and Korobrow, A. 2005. Chromosome numbers in the tribes Anthemideae and Inuleae (Asteraceae). Botanical Journal of the Linnean Society 148: 77-85.

— and Siljak-Yakovlev, S. 1997. Cytogenetic studies in the genus Artemisia L. (Asteraceae): fluorochrome-banded karyotypes of five-taxa, including the lberian endemic species Artemisia barrelieri Besser. Can. J. Bot. 75: 595-606.

— and Torrel M. 1995. Reports (552-558). In: Kamari, G., Felber, F. and Garbari, F. (eds.), Mediterranean chromosome number reports-5. Fl. Medit. 5: 357-363.

Volkova, S. A. and Boyko, E. V. 1986. Chisla khromosom nekotorikh vidov semeistva Asteraceae iz iuzhnoi chasti Sovestkogo dalnego vostoka. [Chromosome numbers in some species of Asteraceae family from the southern part of the Soviet far east. Botanicheskii Zhurnal 71: 1693.

Watanabe, W. 2002. Index to chromosome numbers in Asteraceae. http://www-asteraceae.cla.kobe-u.ac.jp/index.html.

Yan, X. X., Zhang, S. Z., Yan, J. F., Fu, X. Q. and Wang, L. Y. 1989. Chromosome numbers and geographical distribution of 68 species of forage plants. Grassland China 1989: 53-60. 